\title{
PENGARUH DIMENSI EFEKTIVITAS KEPEMIMPINAN TERHADAP KEPUASAN KERJA KARYAWAN RUMAH SAKIT PERMATA BUNDA YOGYAKARTA \\ Farlianto, MBA
}

Email:

Universitas Negeri Yoguakarta

Abstrak

Keberhasilan perusahaan dalam mencapai tujuannya tidak dapat dilepaskan dari peran pemimpinnya. Dalam suatu perusahaan, seorang pimpinan bukan semata-mata sebagai obyek dalam pencapaian tujuan saja tetapi lebih dari itu, seorang pemimpin sekaligus menjadi subyek atau pelaku. Peran penting seorang pemimpin dalam pencapaian tujuan perusahaan ini juga ditegaskan oleh Gibson (1995), bahwa keberhasilan perusahaan sangat ditentukan oleh efektivitas keberhasilan pemimpin dan karyawan dari semua divisi dalam perusahaan. Pendapat Gibson ini mempunyai konsekuensi adanya suatu tuntutan kepada perusahaan untuk lebih memperhatikan aspek-aspek kritis yang merupakan faktor penentu keberhasilan kinerja seorang pemimpin sehingga karyawan dapat meraih kepuasan kerja. Keberhasilan kinerja karyawan secara langsung akan membentuk keberhasilan perusahaan.

Penilaian kepuasan kerja karyawan akan bermanfaat bagi perusahaan. Penilaian kepuasan karyawan hendaknya dilakukan dan ditargetkan oleh seorang pimpinan, hal itu dapat dilakukan antara lain dengan melakukan pengembangan sebagai proses penilaian yang dapat dilakukan antara lain dengan evaluasi faktor situasional kepemimpinan, 
langkah terakhir adalah dengan menghubungkannya dengan penilaian kinerja para karyawannya. (Robbins, 1996).

Kinerja karyawan yang tinggi akan membuat karyawan semakin loyal terhadap perusahaan, semakin termotivasi untuk bekerja, bekerja dengan rasa senang, dan yang lebih penting adalah kepuasan kerja yang tinggi akan memperbesar kemungkinan tercapainya produktivitas dan kinerja yang tinggi pula. Karyawan yang tidak puas akan cenderung sering mengeluh, tidak mematuhi aturan, mencuri milik perusahaan dan mengelakkan diri dari tanggung jawab pekerjaannya (Robbins, 2000); kondisi demikian jika tidak mendapat perhatian dan penanganan dari pihak atasan jelas akan mengganggu jalannya proses pencapaian tujuan perusahaan. Oleh karena itu seorang pemimpin dituntut untuk mampu memadukan dan mengkombinasikan berbagai sumber kekuasaan yang dimiliki untuk mendorong kinerja bawahannya, berhasil atau tidaknya akan tergantung pada perilaku pimpinan tersebut, bagaimana ia mengenali situasi dan kondisi diri pribadi dan lingkungannya karena akan memegang peranan penting dalam efektivitas kepemimpinannya.

Kepemimpinan sebagai salah satu penentu arah dan tujuan organisasi harus mampu mensikapi perkembangan zaman ini. Pemimpin yang tidak dapat mengantisipasi dunia yang sedang berubah ini, atau setidaknya tidak memberikan respon, besar kemungkinan akan memasukkan organisasinya dalam situasi stagnasi dan akhirnya mengalami keruntuhan. Pertumbuhan dan perkembangan organisasi bisnis selalu dibayangi oleh persaingan usaha yang ketat sehingga organisasi bisnis membutuhkan adanya konsentrasi dan keseriusan pada diri pemimpin terhadap perjalanan roda usaha 
Pemimpin dengan gaya kepemimpinannya menentukan Strategi Perusahaan baik jangka panjang maupun jangka pendek. Corporate Strategy atau Business Srategy merupakan strategi perusahaan untuk mencapai tujuan jangka panjang, untuk itu yang menentukan strategi ini adalah pimpinan puncak, dan pemilik perusahaan. Sedangkan strategi fungsi yaitu strategi yang setiap tahunnya dirubah oleh Departemen dikatakan strategi jangka pendek yang ditentukan oleh pimpinan menengah.

Peranan dan tanggung jawab seorang pemimpin sangat besar terhadap karyawan, apabila seorang pemimpin kurang mampu melihat keadaan para karyawan dan lingkungan disekitarnya akan mengakibatkan penolakan terhadap perintah atasan, pembangkangan, keadaan acuh tak acuh terhadap keberadaan pimpinan dan kurang hormatnya pada pimpinan, sampai pada menurunan motivasi kerja dan akhirnya penurunan kinerja karyawan (Nurmianto, 2003). Dengan berjalannya waktu dan tiba ke masa abad informasi seperti sekarang ini, perusahaan baik jasa maupun manufaktur dituntut untuk memiliki kemampuan baru yang kompetitif, yaitu kemampuan untuk memobilisasi dan mengeksploitasi aktiva tak berwujud. Dengan makin meningkatnya tingkat pendidikan, status sosial, ekonomi masyarakat dan perkembangan IPTEK, perubahan pola penyakit, juga sistem informasi yang semakin canggih, serta kesadaran mesyarakat akan pentingnya kesehatan. Membuat para pengelola rumah sakit senantiasa menyesuaikan produk pelayanan 
yang sesuai dengan yang diinginkan masyarakat. Meningkatnya kesadaran masyarakat akan hidup sehat membawa dampak bertambah pula jumlah pelayanan kesehatan yang dihadapi dalam usaha jasa perlayanan kesehatan dan menambah persaingan. Upaya untuk mencegah terjadinya penurunan pemanfaatan jasa pelayanan rumah sakit, maka rumah sakit harus mampu meningkatkan kepuasan kerja karyawannya agar berproduktivitas tinggi. Sadar akan bahaya persaingan yang akan terjadi. Pihak rumah sakit perlu meningkatkan kepuasan kerja SDM-nya melalui kepemimpinan yang efektif dan sesuai tujuan organisasi.

Rumah Sakit Permata Bunda merupakan rumah sakit yang siap memberikan pelayanan kesehatan bagi masyarakat tanpa membedakan latar belakang pasien, baik dari sisi ekonomi, etnik, suku, golongan dan yang lainnya. Rumah Sakit Permata Bunda berusaha memenuhi tuntutan masyarakat yang makin tinggi yaitu dengan menyediakan pelayanan kesehatan yang bermutu dengan biaya yang terjangkau, sedangkan jenis pelayanan yang diberikan merupakan pelayanan umum dan spesialistik. Rumah Sakit Permata Bunda memberikan pelayanan kesehatan yang profesional dan mewujudkan pelayanan yang senantiasa mengutamakan mutu dan kepuasan pasien terutama ibu dan anak. Rumah Sakit Permata Bunda memiliki visi sebagai monumen yang ikut mewujudkan masyarakat DIY dan sekitarnya menjadi sejahtera kesehatan dan perkembangan jiwa raganya, melalui cara-cara yang profesional, mutu dan paripurna guna 
memenangkan persaingan global. Untuk mencapai visi tersebut diperlukan kinerja sumber daya yang handal. Kinerja tersebut dibentuk oleh karyawan yang memiliki kepuasan kerja yang baik. Hal penting yang perlu untuk diperhatikan dalam mencapai tujuan tersebut adalah masalah kepemimpinan yang efektif agar dapat meningkatkan kepuasan karyawan Rumah Sakit Permata Bunda. Mengingat kepemimpinan berperan dalam membentuk kepuasan kerja karyawan, maka akan dilakukan penelitian mengenai pengaruh kepuasan kerja terhadap kepuasan kerja karyawan Rumah Sakit Permata Bunda dengan judul “Pengaruh Dimensi Efektivitas Kepemimpinan Terhadap Kepuasan Kerja Karyawan Rumah Sakit Permata Bunda Yogyakarta"

Permasalahan dalam penelitian ini akan dirumuskan dengan pertanyaan sebagai berikut:

1. Apakah faktor situasional efektivitas kepemimpinan yang meliputi hubungan pimpinan - bawahan, struktur tugas, dan kekuatan posisi pemimpin secara serentak mempunyai pengaruh yang signifikan terhadap kepuasan kerja karyawan?

2. Apakah faktor situasional efektivitas kepemimpinan yang meliputi hubungan pimpinan - bawahan, struktur tugas dan kekuatan posisi pemimpin secara parsial mempunyai pengaruh yang signifikan terhadap kepuasan kerja karyawan? 


\section{Teori Pengaruh Efektivitas Kepemimpinan terhadap Kepuasan}

\section{Kerja}

Kepuasan kerja karyawan terbentuk karena adanya faktor yang melatarbelakanginya. Pada bagian ini akan dilihat beberapa faktor yang mempengaruhi kepuasan kerja dari beberapa penulis dan peneliti, untuk selanjutnya dipilih beberapa faktor yang terpenting.

Variabel-variabel yang menentukan kepuasan kerja adalah: kerja yang secara mental menantang, ganjaran yang pantas, kondisi kerja yang mendukung, dan rekan sekerja yang mendukung (Locke,1976:63). Katzel menyatakan bahwa karyawan cenderung menyukai pekerjaanpekerjaan yang secara mental menantang. Pada kondisi tantangan yang sedang, kebanyakan karyawan akan mengalami kesenangan dan kepuasan (Cranny dan Stone, 1992:81)

Dari penelitian tentang faktor yang mempengaruhi kepuasan kerja karyawan secara signifikan adalah: faktor yang berhubungan dengan pekerjaan, faktor yang berhubungan dengan kepuasan dalam pekerjaan itu sendiri, faktor yang berhubungan dengan teman sekerja, faktor yang berhubungan dengan pengawasan, faktor yang berhubungan dengan promosi jabatan dan faktor yang berhubungan dengan gaji (Indra, 2001; Lancaster, 1998:36).

Bagi kebanyakan karyawan kerja juga mengisi kebutuhan akan interaksi sosial, bila rekan sekerja yang ramah dan mendukung menghantar kepada kepuasan kerja yang meningkat, dan umumnya studi mendapatkan bahwa kepuasan kerja karyawan ditingkatkan bila 
penyelia langsung bersifat ramah dan dapat memahami, menawarkan pujian untuk kinerja yang baik, mendengarkan pendapat karyawan, dan menunjukkan suatu minat pribadi pada karyawan (Robin, 2000:142).

Teori “Kesesuaian Kepribadian-Pekerjaan” menunjukkan bahwa kecocokan yang tinggi antara kepribadian seseorang karyawan dan okupasi akan menghasilkan seorang individu yang lebih terpuaskan (Holland, 1985:55). Sedangkan menurut Mangkunegara (2000:68), faktor yang mempengaruhi kepuasan kerja adalah : 1) faktor pegawai, yaitu kecerdasan, kecakapan khusus, umur, jenis kelamin, kondisi fisik, pendidikan, pengalaman kerja, masa kerja, kepribadian, emosi, cara berpikir, persepsi, dan sikap kerja. 2) Faktor pekerjaan, yaitu jenis pekerjaan, struktur organisasi, pangkat, kedudukan, mutu pengawasan, jaminan finansial, kesempatan promosi jabatan, interaksi sosial, dan hubungan kerja. Hal tersebut memiliki penggolongan yang beragam. Untuk itu, penulis hanya memilih beberapa faktor diantaranya: faktor kondisi kerja, faktor hubungan dengan teman sekerja, faktor yang berhubungan dengan pengawasan, faktor yang berhubungan dengan promosi jabatan/pengembangan karir dan faktor yang berhubungan dengan gaji.

faktor tersebut telah digunakan oleh beberapa penulis seperti Lanchaster (1998:56), Job Description Indeks (Jiewell dan Siegal, 1998:55). 
Skala Indeks Deskripsi Jabatan (Mangkunegara, 2000:68), dan beberapa penelitian sebelumnya seperti Indra (2001:63), Muis (1999:86).

1. Pekerjaan itu Sendiri

Pekerjaan itu sendiri berorientasi kepada apakah kerja yang ada merupakan kerja yang secara mental menantang (Robin, 2000:22). Karyawan cenderung lebih menyukai pekerjaan-pekerjaan yang memberi kesempatan untuk menggunakan keterampilan dan kemampuan pada karyawan dan menawarkan beragam tugas, kebebasan, dan umpan balik mengenai betapa baik karyawan mengerjakan. Karakteristik ini membuat kerja secara mental menantang. Pekerjaan yang terlalu kurang menantang menciptakan kebosanan, tetapi yang terlalu banyak menantang menciptakan frustasi dan perasaan gagal. Abelson (King dan McGinnies, 1972:99) menyatakan pada kondisi tantangan sedang, kebanyakan karyawan akan mengalami kesenangan dan kepuasan.

2. Hubungan dengan Rekan Kerja

Bagi kebanyakan karyawan, kerja juga mengisi kebutuhan akan interaksi sosial. Jika seseorang mempunyai rekan sekerja yang ramah dan mendukung, akan menghantar kepada kepuasan kerja yang meningkat (Robin, 2000:77). Hubungan yang baik dalam kerja timbul karena adanya komunikasi dan kepercayaan diantara rekan kerja yang berinteraksi selama masa kerja. Dalam membangun 
sebuah hubungan dua harus ada saling kepercayaan diantara orang tersebut.

Masalah hubungan kerja ini berhubungan dengan teori kebutuhan Maslow yang menyatakan adanya motivasi seseorang karena kebutuhan sosial. Jika seseorang dalam bekerja diterima dengan baik secara sosial, mampu berinteraksi dengan baik, akan memotivasi dirinya untuk melakukan kerja dan memeroleh kepuasan. Demikian juga dalam teori McClelland, khususnya pada kebutuhan manusia akan berafiliasi (afilliation need), seseorang mengharapkan hubungan yang ramah dan karib dalam dunia kerja (Robin, 2000:163).

3. Pengawasan Atasan-bawahan

Pengawasan merupakan fungsi dari manajemen, pengawasan merupakan proses penentuan apa yang harus dicapai yaitu standar apa yang sedang dilakukan yaitu pelaksanaan, menilai pelaksanaan dan apabila perlu melakukan perbaikan-perbaikan, sehingga pelaksanaan sesuai dengan rencana yaitu selaras dengan standar. Pengawasan (controlling) sebagai aktivitas yang dilaksanakan oleh pihak atasan dalam upaya memasatikan hasil aktual sesuai dengan yang direncanakan.

Pengawasan dari atasan atau pimpinan berperan dalam menunjang kepuasan kerja bawahan. Beck dan Hilman (1983:59) 
menyatakan bahwa kepemimpinan yang positif umumnya menghasilkan kepuasan kerja dan prestasi kerja. Positifnya nilainilai kepemimpinan seorang atasan juga tercermin dalam pengawasan yang dilakukannya, dalam arti pengawasan positif akan menghasilkan kepuasan kerja seseorang.

4. Pengembangan Karir dan Promosi

Karir merupakan sebuah gagasan bahwa orang selalu bergerak maju dan meningkat dalam pekerjaannya. Bergerak maju mengandung arti tuntutan gaji yang lebih besar, mengasumsikan tanggung jawab yang lebih banyak, dan mendapatkan status prestise atau gengsi, dan kekuasaan yang lebih banyak.

Salah satu cara mengembangkan karir pegawai adalah melalui promosi, yakni perpindahan yang memperbesar wewenang dan tangung jawab karyawan ke jabatan yang lebih tinggi di dalam suatu organisasi sehingga kewajiban, hak, status dan penghasilan semakin besar (Hasibuan, 1997:121).

\section{Kebijaksanaan Gaji}

Menurut T. Hani Handoko (1996:85), gaji adalah pemberian kepada karyawan dengan pembayaran finansial sebagai balas jasa untuk pekerjaan yang dilaksanakan dan sebagai motivator untuk pelaksanaan kegiatan di waktu yang akan datang. Sedangkan Hasibuan (1997:133) mendefenisikan gaji sebagai balas jasa yang 
dibayar secara periodik kepada karyawan tetap serta mempunyai jaminan yang pasti.

Kepuasan kerja tergantung dari tingkat perolehan imbalan. Jika perolehan imbalan dirasakan kurang adil, maka pemegang pekerjaan akan mengalami ketidakpuasan dan mencari jalan untuk mencari imbalan yang lebih besar (Gibson, 1992:86).

\section{Hubungan Efektivitas Kepemimpinan Dengan Kepuasan Kerja}

Hubungan pemimpin-bawahan menjadi hubungan yang baik apabila bawahan menghargai, menyukai dan mendukung pemimpin serta bersedia mengikuti arahan pemimpin. Keadaan ini akan memberikan kontrol bagi pemimpin dan memberikan kontribusi situasi yang mengguntungkan pemimpin sehingga terbentuk faktor situasional efektivitas kepemimpinan. Struktur tugas yang tinggi akan memberikan kontribusi pada situasi yang menguntungkan pemimpin dalam memonitor dan mempengaruh perilaku karyawannya sehingga kerja pemimpin menjadi lebih efektif. Kekuatan posisi pemimpin berupa tingkat kewenangan pemimpin untuk mengevaluasi pelaksanaan kerja, dan memberikan penghargaan, promosi maupun hukuman. Semakin besar kekuasaan formal seorang pemimpin akan meningkatkan pengendalian karyawan, hal ini membuat situasi semakin efektif bagi pemimpin. 
Faktor Situasional Efektivitas kepemimpinan

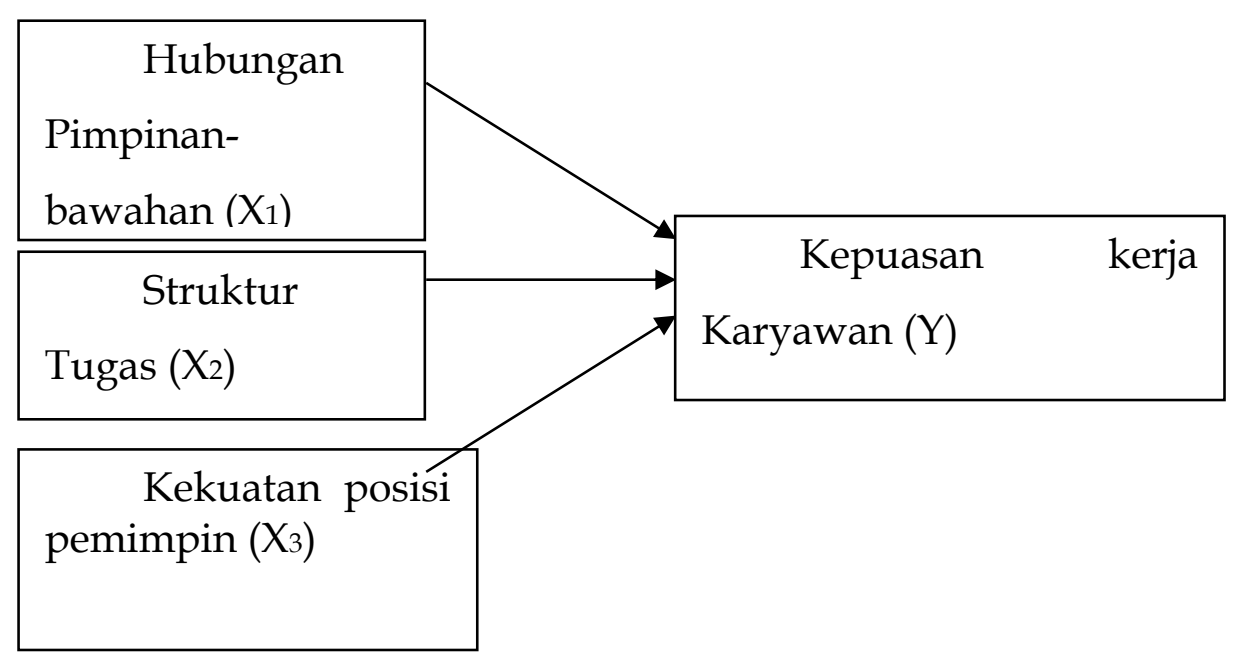

Gambar 2.1. Kerangka Pikiran

Sumber: Teori Contingency Fiedler (Robbins, 1998)

Hipotesis Penelitian

Hipotesis dalam penelitian adalah sebagai berikut:

H1: Efektivitas kepemimpinan yang meliputi hubungan pimpinanbawahan, struktur tugas, dan kekuatan posisi pemimpin secara serentak berpengaruh signifikan terhadap kepuasan kerja karyawan Rumah Sakit Permata Bunda Yogyakarta.

H2: Efektivitas kepemimpinan yang meliputi hubungan pimpinanbawahan, struktur tugas, dan kekuatan posisi pemimpin secara parsial berpengaruh signifikan terhadap kepuasan kerja karyawan Rumah Sakit Permata Bunda Yogyakarta.

Metode Penelitian

Jenis penelitian 
Penelitian yang dilakukan merupakan penelitian survey yaitu penelitian dilakukan dengan mengukur populasi dengan menggunakan sampel pada suatu waktu tertentu, mengembangkan pemahaman tertentu dan hipotesis yang bersifat relatif serta mengidentifikasi permasalahan yang dipilih. Metode yang digunakan dalam penelitian ini adalah populasi survey yang dilakukan di dalam pengumpulan data primer.

\section{Populasi}

Populasi adalah sekumpulan orang atau objek yang memiliki kesamaan dalam beberapa hal yang membentuk masalah pokok (Sugiyono, 2001). Pengertian populasi adalah totalitas semua nilai yang mungkin, hasil menghitung atau pengukuran kuantitatif maupun kualitatif daripada karakteristik tertentu mengenai sekumpulan objek yang lengkap dan jelas yang ingin dipelajari sifat-sifatnya (Azwar, 1992). Populasi dalam penelitian ini adalah seluruh karyawan tetap Rumah Sakit Permata Bunda Yogyakarta yang berjumlah 74 orang. Jumlah populasi tersebut dapat dijangkau oleh penulis sehingga penelitian ini menggunakan populasi tanpa adanya pengambilan sampel yang menggunakan metode sensus.

Uji instrumen penelitian.

a. Uji Validitas 
Uji validitas dilakukan untuk mengetahui apakah suatu instrumen alat ukur telah menjalankan fungsi ukurnya. Menurut Sekaran (2003) validitas menunjukkan ketepatan dan kecermatan alat ukur dalam melakukan fungsi ukurnya. Untuk mengetahui konsistensi dan akurasi data yang dikumpulkan dari penggunaan instrumen dilakukan uji validitas dengan menggunakan korelasi product moment pearson. Suatu skala pengukuran disebut valid bila ia melakukan apa yang seharusnya dilakukan dan mengukur apa yang seharusnya diukur. Bila skala pengukuran tidak valid maka ia tidak bermanfaat bagi peneliti karena tidak mengukur apa yang seharusnya diukur atau melakukan apa yang seharusnya dilakukan. Sebuah item dikatakan valid bila r-hitung > r-tabel (Sugiyono, 2001). Uji validitas dalam penelitian ini dilakukan dengan bantuan program SPSS for Window release 11,0.

Uji Reliabilitas.

Pengujian reliabilitas adalah berkaitan dengan masalah adanya kepercayaan terhadap instrumen. Suatu instrumen dapat memiliki tingkat kepercayaan yang tinggi (konsisten) jika hasil dari pengujian instrumen tersebut menunjukkan hasil yang tetap. Dengan demikian, masalah reliabilitas instrumen berhubungan dengan masalah ketepatan hasil. Uji reliabilitas dilakukan untuk mengetahui tingkat kestabilan suatu alat ukur. Pada penelitian ini, 
uji reliabilitas dilakukan dengan menggunakan pendekatan internal consistency reliability yang menggunakan Cronbach Alpha untuk mengidentifikasikan seberapa baik item-item dalam kuisioner berhubungan antara satu dengan yang lainnya. Sebuah faktor dinyatakan reliabel/handal jika koefisien Alpha lebih besar dari 0,6 (Sugiyono, 2001). Uji reliabilitas juga dilakukan dengan bantuan program SPSS for Window release 11,0.

Data

a. Jenis Data

Penelitian ini menggunakan data primer yang dikumpulkan menggunakan kuesioner. Data primer yang dibutuhkan dalam penelitian ini adalah kepemimpinan dan kepuasan kerja karyawan Rumah Sakit Permata Bunda Yogyakarta. .

b. Alat pengumpulan data

Alat pengumpulan data primer menggunakan kuesioner. Pengukuran atribut kepemimpinan dan kepuasan kerja karyawan dengan skala Likert dari $1=$ sangat tidak setuju hingga $5=$ sangat setuju. Kuesioner dilengkapi dengan data responden.

Variabel Penelitian

Variabel dalam penelitian ini sebagai berikut:

1) Variabel dependen $\quad$ : Kepuasan kerja karyawan $(Y)$ 
2) Variabel independen : Efektivitas Kepemimpinan $(X)$

Metode Analisis Data

a. Analisis Deskriptif

Analisis ini digunakan untuk mengidentifikasi karakteristik responden. Data pribadi yang diperoleh dari jawaban responden dianalisis ke dalam bentuk persentase untuk mempermudah pembacaan data. Karakteristik responden dalam penelitian ini diidentifikasikan berdasarkan jenis kelamin, usia, lama kerja dan pendidikan.

b. Analisis Regresi Linier Berganda sebagai berikut:

Metode analisis yang digunakan adalah analisis regresi berganda. Adapun persamaannya adalah

$Y=\beta_{0}+\beta_{1} X_{1}+\beta_{2} X_{2}+\beta_{3} X_{3}+e$

Keterangan :

$$
\begin{aligned}
& \mathrm{Y} \quad=\text { Variabel dependen, kepuasan karyawan } \\
& \mathrm{X}_{1} \quad=\text { hubungan pimpinan dengan bawahan } \\
& \mathrm{X}_{2} \quad=\text { struktur tugas } \\
& \mathrm{X}_{3} \quad=\text { kekuatan posisi pemimpin } \\
& \mathrm{B}_{0}=\text { konstanta } \\
& \beta_{1}-\beta_{3}=\text { koefisien Regresi } \\
& \text { e } \quad=\text { Suku kesalahan untuk tujuan perhitungan e, } \\
& \text { diasumsikan } 0 . \\
& \text { Definisi Operasional Variabel }
\end{aligned}
$$

Definisi operasional adalah batasan pengertian variabelvariabel yang digunakan dalam penelitian. Definisi operasional diperlukan untuk menjelaskan supaya ada kesamaan penaksiran dan tidak mempunyai arti yang berbeda-beda. 
Kepuasan kerja (Y) yang dimaksud adalah keadaan emosional yang menyenangkan atau tidak menyenangkan bagi para karyawan dalam memandang pekerjaan mereka (Handoko, 2000). Indikator kepuasan kerja adalah gaji $\left(Y_{1.1}\right)$, jaminan kerja $\left(\mathrm{Y}_{1.2}\right)$, pekerjaan itu sendiri $\left(\mathrm{Y}_{1.3}\right)$, Pemilihan Pekerjaan $\left(\mathrm{Y}_{1.4}\right)$, prestasi $\left(\mathrm{Y}_{1.5}\right)$ dan penghargaan terhadap kinerja karyawan $\left(\mathrm{Y}_{1.6}\right)$.

Faktor situasional efektivitas pemimpin yang dimaksud dalam penelitian ini efektivitas kerja pemimpin yang akan dilihat dari tiga variabel situasional yaitu hubungan pimpinan bawahan (X1), struktur tugas (X2) dan kekuatan posisi pemimpin (X3) (Robbins, 1996:139). Faktor situasional efektivitas kepemimpinan didefinisikan sebagai keefektifan kepemimpinan yang berorientasi pada hubungan pimpinan-bawahan (leadermember relation), struktur tugas (task-structure) dan kekuatan posisi pemimpin (leader position power). Gaya kepemimpinan yang berorientasi kepada karyawan atau bawahan (X1). Indikator hubungan pimpinan-bawahan meliputi hubungan yang baik antara pimpinan dengan bawahan $\left(\mathrm{X}_{1.1}\right)$, pemimpin melibatkan bawahan dalam pengambilan keputusan $\left(\mathrm{X}_{1.2}\right)$, pemimpin memberikan motivasi kepada bawahan $\left(X_{1.3}\right)$, pemimpin mendorong bawahan untuk mengajukan saran $\left(X_{1.4}\right)$, pemimpin mengutamakan kontribusi saran dari bawahan $\left(X_{1.5}\right)$.

Gaya yang berorientasi pada tugas atau struktur tugas (X2). Indikator Gaya yang berorientasi pada tugas atau struktur tugas meliputi pemimpin mendesentralisasikan wewenang kepada bawahan $\left(\mathrm{X}_{2.1}\right)$, pemimpin menyusun jadwal dengan baik $\left(\mathrm{X}_{2.2}\right)$, pemimpin memberikan petunjuk kepada bawahan $\left(\mathrm{X}_{2.3}\right)$, pemimpin menyusun prosedur dalam melaksanakan tugas $\left(\mathrm{X}_{2.4}\right)$, 
pemimpin lebih menekankan kepada pelaksanaan tugas yang sesuai kemampuan karyawan $\left(\mathrm{X}_{2.5}\right)$.

Gaya kepemimpinan yang berorientasi pada kekuatan posisi pemimpin (X3). Indikator kekuatan posisi pemimpin meliputi pemimpin yang sering menghindari kekuasan otoriter (X3.1), bergantung pada kelompok untuk menetapkan tujuan perusahaan $\left(\mathrm{X}_{3.2}\right)$, memotivasi bawahan $\left(\mathrm{X}_{3.3}\right)$, bertanggung jawab dalam menghadapi kejadian yang terjadi dalam perusahaan $\left(\mathrm{X}_{3.4}\right)$, bergantung pada kelompok untuk menanggulangi masalah yang terjadi $\left(X_{3.5}\right)$.

\section{Karakteristik Responden Penelitian}

Jumlah karyawan RS Permata Bunda sebanyak 74 orang. Responden dalam penelitian ini dapat dikategorikan dalam beberapa karakteristik responden, yaitu berdasarkan usia, jenis kelamin, jenjang pendidikan, dan masa kerja responden. Uraian berikut ini merupakan penjelasan karakteristik demografis responden tersebut. Komposisi karyawan berdasarkan jenis kelamin adalah sebagai berikut:

\section{Tabel 1}

Karakteristik Responden Berdasarkan Jenis kelamin

\begin{tabular}{|c|c|c|}
\hline $\begin{array}{c}\text { Jenis } \\
\text { Kelamin }\end{array}$ & Jumlah & Persentase \\
\hline Pria & 26 & $36 \%$ \\
\hline Wanita & 46 & $64 \%$ \\
\hline Total & 72 & $100 \%$ \\
\hline
\end{tabular}

Sumber: Data Primer 
Dari tabel di atas dapat diidentifikasi bahwa dari total 72 responden dalam penelitian ini, jumlah responden pria adalah 26 responden atau $36 \%$, sedangkan jumlah responden wanita adalah 46 responden atau $64 \%$. Komposisi tersebut menunjukkan bahwa karyawan dalam penelitian ini didominasi oleh karyawan wanita karena bergerak di bidang pelayanan.

Komposisi responden berdasarkan usia secara rinci diperlihatkan dalam tabel di bawah ini:

\section{Tabel 2}

\section{Karkateristik Responden Berdasarkan Usia}

\begin{tabular}{|c|c|c|}
\hline $\begin{array}{c}\text { Usia } \\
\text { (tahun) }\end{array}$ & Jumlah & Persentase \\
\hline $17-26$ & 23 & $32 \%$ \\
\hline $27-36$ & 37 & $51 \%$ \\
\hline $37-46$ & 7 & $10 \%$ \\
\hline$>46$ & 5 & $7 \%$ \\
\hline Total & 72 & $\%$ \\
\hline
\end{tabular}

Sumber: Data Primer

Dari tabel di atas dapat diidentifikasi bahwa komposisi usia responden dalam penelitian ini yaitu usia responden terendah 17-26 tahun dan tertinggi $>46$ tahun. Responden yang berusia 17-26 tahun berjumlah 23 orang atau sebesar 32\%, yang berusia 27-36 tahun berjumlah 37 orang atau sebesar 51\%, yang berusia 37-46 tahun berjumlah 7 orang atau sebesar 10\% dan yang berusia di atas 46 
tahun sebanyak 5 atau sebesar 7\%. Dengan demikian, mayoritas karyawan dalam penelitian ini berusia 17-36 tahun.

Komposisi karyawan berdasarkan jenjang pendidikan akhir adalah sebagai berikut:

\section{Tabel 3}

\section{Karyawan Berdasarkan Pendidikan Akhir}

\begin{tabular}{|l|l|l|}
\hline Pendidikan & Jumlah & Persentase \\
\hline SD & 4 & $6 \%$ \\
\hline SMP & 6 & $8 \%$ \\
\hline SMU & 11 & $15 \%$ \\
\hline Diploma & 37 & $51 \%$ \\
\hline Strata 1 & 14 & $20 \%$ \\
\hline Total & 72 & $100 \%$ \\
\hline
\end{tabular}

Sumber: Data diolah

Dari tabel di atas dapat diidentifikasi bahwa karyawan yang berpendidikan SD sebanyak 4 orang atau sebesar 6\%, karyawan yang berpendidikan SMP sebanyak 6 orang atau sebesar $8 \%$, karyawan yang berpendidikan SMU sebanyak 11 orang atau sebesar 15\%, karyawan yang berpendidikan Diploma sebanyak 37 orang atau sebesar 51\%, karyawan yang berpendidikan Strata 1 sebanyak 14 orang atau sebesar 20\%. Dengan demikian mayoritas responden dalam penelitian ini adalah karyawan yang berpendidikan Diploma.

Komposisi responden berdasarkan lama bekerja adalah sebagai berikut:

\section{Tabel 4}




\section{Responden Berdasarkan Lama Bekerja}

\begin{tabular}{|l|l|l|}
\hline Pendidikan & Jumlah & Persentase \\
\hline$\leq 3$ tahun & 27 & $37 \%$ \\
\hline $3,1-5$ tahun & 35 & $49 \%$ \\
\hline$>5$ tahun & 10 & $14 \%$ \\
\hline Total & 72 & $100 \%$ \\
\hline
\end{tabular}

Sumber: Data Primer

Dari tabel di atas dapat diidentifikasi bahwa responden yang memiliki masa kerja kurang dari 3 tahun sebanyak 27 orang atau $37 \%$, responden yang memiliki masa kerja kurang dari 3,1-5 tahun sebanyak 35 orang atau 49\%, sedangkan responden yang memiliki masa kerja lebih dari 5 tahun sebanyak 10 orang atau $14 \%$.

\section{Uji Instrumen Penelitian}

Sebelum melakukan analisis data, data penelitian terlebih dahulu dilakukan uji validitas dan reliabilitas data penelitian. Uji validitas dalam penelitian ini menggunakan metode korelasi product moment pearson sedangkan uji reliabilitas menggunakan cronbach alpha dengan alat bantu statistik SPSS for Windows versi 11.

Untuk mengetahui konsistensi dan akurasi data yang dikumpulkan dari penggunaan instrumen dilakukan uji validitas dengan menggunakan Korelasi Product Moment Pearson. Suatu skala pengukuran disebut valid bila variabel melakukan apa yang seharusnya dilakukan dan mengukur apa yang seharusnya diukur. Bila skala pengukuran tidak valid maka ia tidak bermanfaat bagi peneliti karena tidak mengukur apa yang seharusnya diukur atau melakukan apa yang seharusnya dilakukan (Sugiyono, 2001). Uji validitas dilakukan dengan mengkorelasi antara skor yang diperoleh untuk masing-masing pertanyaan dengan skor total. Sebuah item dinyatakan valid/sahih apabila r-hitung lebih besar dari r- 
tabel (Sugiyono, 2001). Dengan populasi penelitian sebanyak 72 orang maka ditemukan besarnya r-tabel yaitu 0,228 dan berdasarkan hasil uji validitas menggunakan korelasi produk momen pearson diketahui bahwa semua variabel valid/sahih. Menurut Cooper (2000:128) sebuah variabel dikatakan valid apabila r-hitung > r-tabel.

Berdasarkan hasil uji reliabilitas menggunakan cronbach alpha diketahui bahwa semua variabel reliabel. Menurut Cooper (2000) sebuah variabel dikatakan reliabel apabila alpha $>0,6$.

Analisis Data

Analisis kuantitatif biasanya digunakan untuk menganalisis suatu masalah agar dapat memberikan gambaran secara kongkrit sehingga dapat diambil kesimpulan secara pasti. Analisis kuantitatif yang digunakan dalam penelitian ini adalah Analisis Linier Berganda, model ini dipilih untuk mengetahui besarnya pengaruh variabel faktor situasional efektivitas kepemimpinan (X) terhadap kepuasan kerja (Y) karyawan RS Permata Bunda . Untuk lebih jelas dapat dilihat pada Tabel 1 berikut ini.

Tabel 5.

Perhitungan Regresi Linier Berganda dimensi efektivitas kepemimpinan

\begin{tabular}{|c|c|c|c|c|c|}
\hline \multirow[t]{2}{*}{ Keterangan } & \multicolumn{2}{|c|}{$\begin{array}{l}\text { Unstandardized } \\
\text { Coefficients }\end{array}$} & \multirow{2}{*}{$\begin{array}{l}\text { Standardize } \\
\text { Coefficients } \\
\text { Beta }\end{array}$} & \multirow[b]{2}{*}{$\mathrm{t}$} & \multirow[b]{2}{*}{ Sig. } \\
\hline & $\mathrm{B}$ & Std.Error & & & \\
\hline $\begin{array}{l}\text { (Constant) } \\
\text { Hubungan } \\
\text { pimpinan- }\end{array}$ & 8.435 & 3.103 & & 2.718 & 0.007 \\
\hline $\begin{array}{l}\text { bawahan } \\
\text { Struktur }\end{array}$ & 0.334 & 0.070 & 0.040 & 3.481 & 0.031 \\
\hline tugas & 0.331 & 0.126 & 0.205 & 4.623 & 0.010 \\
\hline
\end{tabular}




\begin{tabular}{|c|c|c|c|c|c|}
\hline $\begin{array}{c}\text { Kekuatan } \\
\text { posisi pemimpin }\end{array}$ & 0.396 & 0.095 & 0.346 & 4.886 & 0.000 \\
\hline
\end{tabular}

Sumber: Data Primer

Dari tabel di atas dapat dirumuskan suatu persamaan regresi untuk efektivitas kepemimpinan sebagai berikut:

$$
\mathrm{Y}=8,435+0.334 \mathrm{X}_{1}+0.331 \mathrm{X}_{2}+0.396 \mathrm{X}_{3}
$$

Dimana:

$$
\begin{aligned}
& \mathrm{Y}=\text { Kepuasan karyawan } \\
& \mathrm{X} 1=\text { Hubungan pimpinan-bawahan } \\
& \mathrm{X} 2=\text { Struktur tugas } \\
& \mathrm{X} 3=\text { Kekuatan posisi pemimpin }
\end{aligned}
$$

Dari persamaan Regresi tersebut dapat dilihat bahwa kekuatan posisi pemimpin memiliki koefisien tertinggi yaitu 0.396 sehingga dimensi ini merupakan variabel yang dominan berpengaruh terhadap kepuasan karyawan. Variabel-variabel lain yang mempengaruhi kepuasan karyawan (Y) berdasarkan besarnya nilai koefisien berturut-turut adalah Hubungan pimpinan-bawahan (X1) dengan koefisien 0,040, struktur tugas (X2) dengan koefisien 0,331, dan kekuatan posisi pemimpin dengan koefisien 0,396. Besarnya nilai pengaruh tersebut ditunjukkan oleh nilai $\mathrm{R}^{2}=18.9 \%$ yaitu persentase pengaruh variabel hubungan pimpinan-bawahan, struktur tugas, dan kekuatan posisi pemimpin terhadap perubahan tingkat kepuasan karyawan adalah sebesar $18.9 \%$. Variabel lain yang menjelaskan variasi perubahan tingkat kepuasan karyawan secara menyeluruh adalah sebesar $81.1 \%$.

Sebagai dasar untuk menerima atau menolak hipotesis tersebut di atas, dilakukan pengujian menggunakan F-Test dalam analisis Regresi Linier Berganda dengan program SPSS for Windows Release 10. Pengujian 
dilakukan dengan taraf signifikansi 0.05 atau tingkat kepercayaan 95\% dua sisi (2-tailed).

Dari uji $\mathrm{F}$, didapat $\mathrm{F}$ hitung adalah 10,482 dengan tingkat signifikansi 0,000. Karena probabilitas $(0,000)$ jauh lebih kecil dari 0,05 maka model regresi dapat dipakai untuk memprediksi kepuasan karyawan. Hasil $\mathrm{F}$ hitung tersebut jika dibandingkan dengan $\mathrm{F}$ tabel pada tingkat keyakinan 95\% $(\alpha=0,05)$. Pada Tabel 4.9 dapat dilihat bahwa F hitung yang dihasilkan sebesar 10,482, lebih besar dari F tabel pada taraf nyata $95 \%(\alpha=0,05)$ yaitu sebesar 2,75 , ini berarti Ho ditolak dan Ha diterima. Hal ini menunjukkan bahwa variabel bebas yang terdiri dari variabel hubungan pimpinan-bawahan, struktur tugas dan kekuatan posisi pemimpin secara serentak berpengaruh terhadap variabel terikat yaitu kepuasan karyawan.

Sebagai dasar untuk menerima atau menolak hipotesis kedua, dilakukan pengujian hubungan kausal menggunakan Analisis Regresi Linier Berganda (Multiple Linier Regression) dengan program SPSS for Windows Release 10. Sebagai dasar untuk menerima atau menolak hipotesis tersebut di atas, dilakukan pengujian menggunakan $t$-test dalam analisis Regresi Linier Berganda dengan program SPSS for Windows Release 10. Pengujian dilakukan dengan taraf signifikansi 0.05 atau tingkat kepercayaan 95\% dua sisi (2-tailed).

a) Pengujian terhadap koefisisen regresi hubungan pimpinan-bawahan $\left(\mathrm{X}_{1}\right)$

Untuk menguji pengaruh variabel hubungan pimpinan-bawahan dengan membandingkan $t$ hitung sebesar 3.481 dan tabel 1,980 yang berarti $t_{\text {hitung }}>t_{\text {tabel}}$, sehingga dapat disimpulkan bahwa variabel hubungan pimpinan-bawahan secara parsial berpengaruh terhadap kepuasan karyawan. Hal yang mendasari kesimpulan ini adalah pemimpin dalam proses pengambilan keputusan melibatkan bawahan, 
pemimpin mendorong bawahannya dalam mengajukan saran atau gagasan, bawahan merasa memiliki hubungan yang baik dengan pimpinan serta pemimpin mengutamakan saran karyawan dalam pengambilan keputusan.

b) Pengujian terhadap koefisisen regresi struktur tugas $\left(X_{2}\right)$

Untuk menguji pengaruh variabel struktur tugas terhadap kepuasan karyawan dengan membandingkan thitung sebesar 4.623 dan $t_{\text {tabel }} 1,980$ yang berarti $t_{\text {hitung }}>t_{\text {tabel, }}$ sehingga dapat disimpulkan bahwa variabel struktur tugasecara parsial berpengaruh terhadap kepuasan karyawan.

c) Pengujian terhadap koefisisen regresi posisi pemimpin $\left(X_{3}\right)$

Untuk menguji pengaruh variabel kekuatan posisi pemimpin terhadap kepuasan kerja karyawan dengan membandingkan $t$ hitung sebesar 4,886 dan $t_{\text {tabel }} 1,980$ yang berarti $t_{\text {hitung }}>t_{\text {tabel, }}$ sehingga dapat disimpulkan bahwa variabel kekuatan posisi pemimpin secara parsial berpengaruh terhadap kepuasan karyawan.

Hasil Analisis Regresi menunjukkan bahwa faktor situasional efektivitas kepemimpinan secara serentak berpengaruh terhadap kepuasan karyawan RS Permata Bunda Yogyakarta terbukti karena ketiga variabel bebas yaitu hubungan pimpinan bawahan $\left(X_{1}\right)$, struktur tugas $\left(\mathrm{X}_{2}\right)$, dan kekuatan posisi pemimpin $\left(\mathrm{X}_{3}\right)$ secara serentak mempengaruhi kepuasan kerja karyawan RS Permata Bunda Yogyakarta. Ini terbukti menunjukkan Fhitung sebesar 10,482 lebih besar dari nilai Ftabel pada taraf nyata 95\% sebesar 2,68, karena Fhitung lebih besar dari Ftabel maka Ho ditolak dan Ha diterima yang berarti faktor situasional efektivitas kepemimpinan berpengaruh secara serentak terhadap kepuasan kerja RS Permata Bunda Yogyakarta.

Adanya pengaruh faktor situasional efektivitas kepemimpinan terhadap kepuasan kerja karyawan, pihak manajemen RS Permata Bunda dalam meningkatkan kepuasan kerja karyawan perlu mempertimbangkan 
faktor situasional efektivitas kepemimpinan kepala toko (store manager) dan supervisor-supervisor toko. Variabel yang paling berperan dalam mempengaruhi kepuasan karyawan adalah struktur tugas. Struktur tugas yang jelas dari pimpinan akan meningkatkan kepuasan kerja karyawan

\section{Kesimpulan}

Berdasarkan dari berbagai analisis dan pembahasan pada bab-bab sebelumnya, maka dapat ditarik kesimpulan mengenai pengaruh efektivitas kepemimpinan terhadap kepuasan kerja karyawan RS Permata Bunda Yogyakarta sebagai berikut:

1. Efektivitas kepemimpinan secara serentak maupun parsial berpengaruh terhadap kepuasan karyawan RS Permata Bunda Yogyakarta terbukti karena ketiga variabel bebas yaitu hubungan pimpinan bawahan (X1), struktur tugas (X2), dan kekuatan posisi pemimpin (X3) secara serentak mempengaruhi kepuasan kerja karyawan RS Permata Bunda Yogyakarta.

2. Besarnya nilai pengaruh tersebut ditunjukkan oleh nilai $\mathrm{R}^{2}=18.9 \%$ yaitu persentase pengaruh variabel hubungan pimpinan-bawahan, struktur tugas, dan kekuatan posisi pemimpin terhadap perubahan tingkat kepuasan karyawan adalah sebesar 18.9\%. Variabel lain yang menjelaskan variasi perubahan tingkat kepuasan karyawan secara menyeluruh adalah sebesar $81.1 \%$.

\section{Saran}

Berdasarkan pada kesimpulan yang dikemukakan di atas serta penjelasan pada bab sebelumnya, maka penulis dapat memberi saran yang mungkin bermanfaat bagi pihak manajemen perusahaan. 
1. Dengan adanya pengaruh faktor situasional efektivitas kepemimpinan terhadap kepuasan kerja karyawan, pihak manajemen RS Permata Bunda dalam meningkatkan kepuasan kerja karyawan perlu mempertimbangkan faktor situasional efektivitas kepemimpinan kepala toko (store manager) dan supervisor-supervisor toko. Variabel yang paling berperan dalam mempengaruhi kepuasan karyawan adalah struktur tugas. Struktur tugas yang jelas dari pimpinan akan meningkatkan kepuasan kerja karyawan.

2. Dalam berbagai situasi kerja, pemimpin harus mampu menyesuaikan gaya kepemimpinan baik dari segi hubungan pimpinan-bawahan, struktur tugas maupun kekuatan posisi pimpinan. Ketiga variabel tersebut perlu diperhatikan oleh pimpinan perusahaan karena berpengaruh pada kepuasan kerja karyawan.

RS Permata Bunda Dept Store dalam meningkatkan kepuasan karyawan melalui hubungan pimpinan-bawahan perlu menciptakan keadaan dimana bawahan merasa memiliki hubungan yang baik dengan pimpinan, pemimpin dalam proses pengambilan keputusan melibatkan bawahan, selalu mendorong bawahan untuk mengungkapkan gagasan atau saran serta mengutamakan saran karyawan dalam pengambilan keputusan.

\section{DAFTAR PUSTAKA}

Agung M, Harsiwi, 2001. Hubungan Kepemimpinan Transformasional

dan Karakteristik Personal Pemimpin, Kinerja, Pascasarjana UAJY Yogyakarta.

Algifari, 1997, Analisis Regresi, Kasus dan Solusi, BPFE, Yogyakarta 
Beck, Arthut C dan Hilman, Ellis D. 1983. “The Power of Positive Management. Personal Journal". Februari. Hal. 126-131. Dalam Davis, Keith dan Newstrom, John W. 1996. Perilaku dalam Organisasi. Jilid 1, terjemahan, Erlangga, Jakarta.

Cooper, D.R. \& Emory, C.W, 2000, Business Research Methods, Fifth Edition, Chicago: Rhichard D. Irwin, Inc.

Cranny, P.C. C.J. dan Stone, E.F. 1992. Job Satisfaction. Lexington Books. Newyork. Dalam Robin, Stephen P. 1996. Perilaku Organisasi. Konsep. Kontroversi. Aplikasi. Jilid 1. Penerjemah: Hadyana Pujaatmaka dan Benyamin Molan. Penerbit Prenhallindo. Jakarta.

Dessler, Gary, (1992), Manajemen Sumber Daya Manusia (terjemahan), Prenhallindo, Jakarta.

Gibson, James, Jhon M Ivancevich, dan James H Donell Jr, (2003) Organisasi, Perilaku, Struktur,Proses, Binarupa aksara, Jakarta.

Gordon., 1997, Organisasi, Perilaku, Struktur, Proses, Edisi 8, Terjemahan, Bina Rupa Aksara, Jakarta.

Gudjarati, Damodar, 1993, Ekonometrika Dasar, Cetakan Ketiga, Jakarta: Erlangga.

Hadari, Nawawi, 2003, Manajemen Sumber Daya Manusia Untuk Bisnis yang Kompetitif, Edisi 5, Gadjah Mada University Press, Yogyakarta.

Jiewell, L.N. dan Siegall, Marc. 1998. Psikologi Industri/Organisasi Modern, Terjemahan, Archan. Jakarta.

Locke, E.A. 1976. The Nature and Causes of job Satisfaction. Dalam M.D. Dunnette. Handobook of Industrial and Organizational Psychology. Rand MCNally. Chicago. pp. 1319-28. Dalam Robin, Stephen P.. 1996. Perilaku Organisasi. Konsep, Kontroversi. Aplikasi Jilid 1. terjemahan, Prenhallindo. Jakarta. 
Misbahul, Anwar \& Sri Handari Wahyuningsih, 2005, Analisis Ciri Pemimpin, Faktor Situasional dan Kepuasan Kerja, Utilitas, Vol 13 No 1 Januari

Nurmianto, Eko, 2003, Analisa Faktor Kompetensi terhadap Peningkatan Prestasi Kerja dan Perancangan Sistem Penilaian Kinerja Karyawan Berbasis Sistem Informasi, Jurnal Studi Bisnis Vol 1 no 2.

Robbins, Stephen. 2000. Organizational Behaviou,. Pentice - Hall Inc, New Jersey

Ronny, Kountur, 2003. Metode Penelitian, PPM, Jakarta.

Sekaran, Uma , 2003, Research Methods for Business : Skill-Building Approach, Fourth Edition, John Wiley \&nSons Inc, New York.

Simamora, Henry, 1995, Sumber daya Manusia Dalam Organisasi, edisi revisi dan perluasan, PT Gramedia Pustaka Utama, Jakarta.

Soeratno \& Linconlin Arsyad. 1998. Metode Penelitian Untuk Ekonomi dan Bisnis, UPP AMP YKPN, Yogyakarta.

Sugiono, E. Wibowo, 2001, Statistika Penelitian, Edisi I, Alfabeta, Bandung

Suharsimi, Arikunto, 2000. Metodologi Penelitian Bisnis, PT. Rineka Cipta, Jakarta

T. Hani, Handoko, 2000. Manajemen Sumber Daya Manusia. Edisi 2. Badan Penerbit Fakultas Ekonomi, Yogyakarta.

Tri, Mardiana, 2003. Studi Empiris Pengaruh Efektivitas Kepemimpinan terhadap Kinerja, Kompak. No 8 Mei-Agustus. p276-297 